\title{
REGIONAL DISPARITIES IN PRODUCTIVITY OF SMALL AND MEDIUM-SIZED ENTERPRISES IN THE FOOD INDUSTRY
}

REGIONÁLNÍ DISPARITY V PRODUKTIVIT’nMALÝCH A
STř EDNÍCH PODNIKŠ V POTRA VINÁY̌ SKÉM PRŠ MYSLU

Ing. Martina NOVOTNÁ, PH.D.

ING.TOMÁǴVOLEK, PH.D.

ING. JIř Í ALINA, PH.D.

\author{
\begin{tabular}{l|l} 
Katedra ekonomiky & Department of Economics
\end{tabular} \\ Ekonomická fakulta Faculty of Economics \\ Jihol eská univerzita $v$ L eských Budhjovicích University of South Bohemia \\ $\triangle$ Studentská 13, 37363 L eské Budநjovice, Czech Republic \\ E-mail: novotna@ef.jcu.cz,volek@ef.jcu.cz, jalina@ef.jcu.cz.
}

\begin{abstract}
Annotation
The paper deals with regional difference in effectiveness of production factor labour at small and medium-sized enterprises in food industry. Labour productivity was judged in context, i. e. considering development of other indicators as well: technical equipment of labour and capital productivity. On the basis of relationship among indicators productivity of labour, capital and capital-labour ratio were the food industry enterprises in monitored regions divided into 3 groups. The regions StŚední Lechy and Jihozápad were classified as economics successful. It was found that the productivity of labour and its dynamic in particular regions has different size also development, that's largely affected by disparity in the fieldof wages in particular regions.
\end{abstract}

Key words

labour productivity, technical equipment of labour, small and medium-sized enterprises, regions

\section{Anotace}

PŚisp円ek se zabývá regionálními rozdíly v úl innosti výrobního faktoru práce v malých a stŚedních podnicích $v$ potravináŚsém prTmyslu. Produktivita práce byla posuzována v kontextu vývoje souvisejících ukazatelT: technické vybavení práce a produktivita kapitálu. Na základ门vztah丁 mezi thnito ukazateli byly potravináŚské podniky v monitorovaných regionech rozd heny do 3 skupin.

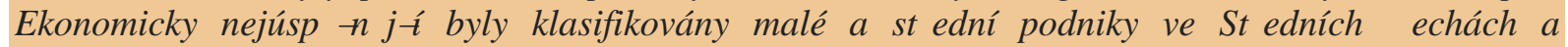
Jihozápadn Dále bylo zjiğhıo, ǵv úroveŔ a dynamika produktivity práce je odlig̉ná v jednotlivých regionech a je do znal né míry ovlivnnıa mzdovou disparitou $v$ jednotlivých regionech.

\section{Klílová slova}

produktivita práce, technické vybavení práce, malé a stŚední podniky, regiony

JEL classification: $R 11$, D24, E23

\section{Introduction}

Labour productivity is the most frequently measured indicator of productivity. Indicator of labour productivity shows the efficiency of utilization factors of production and the production possibility of all economy. Labour productivity we can write as GDP per employee (Belorgey et al., 2006) or value 
added per labour (Broersma, Oosterhaven, 2007). There are two sources of labour productivity growth: technical progress and increases in the average capitalï labour (Kï L) ratio (Guest, 2011). Piacentino,Vassallo (2011) found that capital deepening seems to affect negatively labour productivity growth. Labour productivity is influenced by many shocks. There are two types of structural shocks: (1) technological shocks, that is changes in the technological progress which affects labour productivity in the long-run, and (2) non technological shocks, that is all the other shocks that affect labour productivity temporarily through its effects on capital accumulation and aggregate demand (Travagliny, 2012). Labour productivity is also influenced by business cycle. Labour productivity is pro-cyclical in the real business cycle model, despite the assumption of diminishing marginal returns to labour input, because booms are periods in which technological conditions are particularly favourable. (Bernanke,Parkinson, 1991).

Labour productivity can be measured at the corporate and regional levels. The size and dynamics of labour productivity in the regions is one of indicators of regional competitiveness (Ramik et al. 2010). Aglomeration (regions) may yield the positive and negative effects on the dynamics of productivity (Antonelli et al .,2011). Several studies focus on convergence labour productivity and the hypothesis of convergence among regions (Enflo 2010, Piacentino,Vassallo, 2011). Lopez-Bazo et al. (1999) found a tendency to convergence in labour productivity across European regions. On the other hand Fiaschi, Lavezzi (2007) showed that the distribution of labour productivity in European regions tends to a bimodal distribution.

We have other types of productivity as capital productivity or total factor productivity. The capital productivity shows how productively capital is used to generate value added. Total factor productivity measure technological change. Total factor productivity determines labour productivity, not only directly, but also indirectly by determining capital per worker (Prescott, Lawrence, 1997).

\section{Methodology}

The aim of this paper was to investigate regional differences in the efficiency of the production factor labour in small and medium-sized enterprises in Division 10 - Manufacture of food products (NACE 2). The efficiency of the production factor labour (labour productivity) was assessed in context, i.e. with regard to the development and additional indicators: technical work equipment, capital productivity. Monitored indicators have been defined with regard to the availability and comparability of data at the sector level as well as business data. At the sector level, labour productivity was determined as a proportion of gross value added and compensations to employees, at the corporate level as a quotient of value addedand in labourcosts. The substantive content of givenindicators is not completely identical, however, the gross value added in shorter period is estimated on the basis of value added and compensation of employees are essentially labourcosts i.e. labour costs, including social and health insurance. Technical equipment oflabour was defined as the quotient of gross fixed capital formation and compensation of employees, in other words, as the proportion of tangible and intangible assets and labourcosts.

As a source of data for the reference sector was used the National Account, enterprise data were drawn from a database of ALBERTINA holdings for 6 years (2007-2012). Data of enterprises are surveyed at 383 companies in the Czech Republic, whose principal activity is the food industry; these companies have been throughout the period fixed. In each year, according to the EU methodologies (European Commission Directive (ES) No. 800/2008) were enterprises divided by size. According to the Operational programme of industry and enterprise is considered as small and medium-sized enterprise micro, small and medium enterprise according to EU methodology. Number of micro, small and medium enterprises was slightly changing depending on the change in the conditions for inclusion in the large-size classes (number of employees, turnover, balance sheet total).

Another aim of the analysis of the indicators given was to assess their development and relationships within individual regions. The motive was to assess the proportional development between the evolution of the volume of fixed assets $\mathrm{C}$, L labour costs and the volume of value added $\mathrm{Y}$. The 
relation between labour productivity, capital productivity and technical work equipment can be written: $\frac{Y}{C}=\frac{Y}{L}: \frac{C}{L}$, where $\mathrm{Y} / \mathrm{C}$ is the capital productivity, $\mathrm{CP}, \mathrm{Y} / \mathrm{L}$ is the labour productivity, $\mathrm{LP}$ and $\mathrm{C} / \mathrm{L}$ is the technical equipment of labour (capital-labour ratio, CLR).

The same relations are valid for indices of these indicators:

$$
I_{C P}=I_{L P}: I_{C L R} \quad \frac{C P_{1}}{C P_{0}}=\frac{L P_{1}}{C L R_{1}}: \frac{L P_{0}}{C L R_{0}}
$$

If the index of capital productivity is equal to one, it is clear that the index of labour productivity is equal to the index of technical equipment of labour and the labour productivity grows proportionally to technical equipment of labour. This relationship is characterized by a neutral type of technical business development. It does not change the permanent production use, it does not change the cost per unit of production, theenterprise achieves the effect only by expanding the production. This type of technological development represents extensive type of production.

If $I_{C P}>1$ then $I_{L P}>I_{C L R} \quad$ This is a saving type of technical development. The

efficacy of fixed assets increases, the volume of fixed assets in relation to the value added grows disproportionately. There is a relative saving in fixed costs, and this is considered to be a consistently profitable type of development.

If $\quad I_{C P}<1$ then $I_{L P}<I_{C L R} \quad$ This is a challenging type of technical development.

Labour productivity grows slowly than the technical equipment of labour, it occurs to the lower utilisation of production-permanent load. Costs per unit of production are growing. This can occurif long-term assets, having a production capability, grow simultaneously with the same or faster growth of the output of the company, such as investment in infrastructure and others. (StŚlel ek, Lososová, 2003).

\section{Results and discussion}

At First, attention was focused on the evaluation of the development of labour productivity in the food industry in monitored years both at the level of the national economy (section C Manufacturing in more detail in Section 10 ï Food industry - NACE 2), and at the corporate level.

The purpose of these actions was also, among others, to verify whether the sample of enterprises is sufficiently representative. Labour productivity index is affected not only by the output, i.e. value added, but also by a large extent the intended inputs. Production factor labour is understood as the cost of labour. And thatô how regional differences resulted by the different levels of average wages affect the size of this indicator. Higher wage average level will affect inversely levels of productivity of labour.

Fig. 1: Labour productivity in CZK (value added / labour costs) 


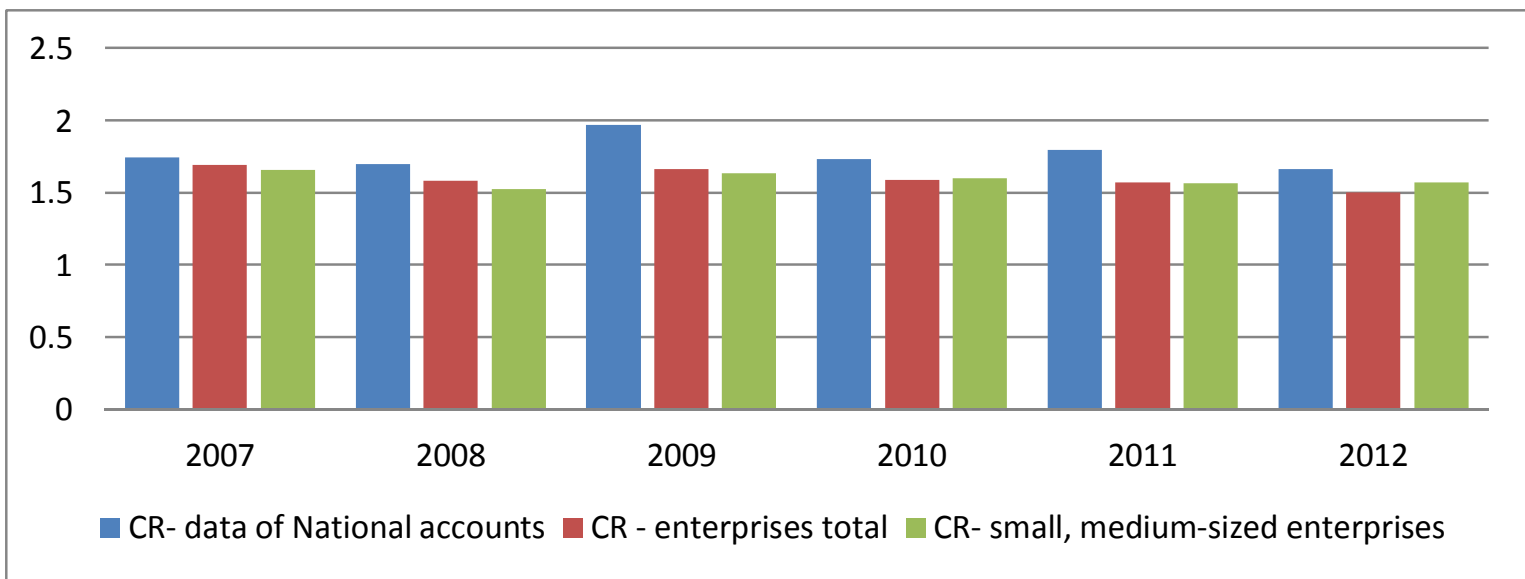

Source: Own calculations based on the data of National accounts, database ALBERTINA From figure 1 it is partly possible to compare the productivity expressed at the national level (share of gross value added and compensation of employees) and at the corporate level (share of book value added and labour costs). From a material standpoint, these indicators can be considered comparable. The value added in the profit and loss account in enterprises engaged in the production of food products is in large part created by differences between performance and power consumption. From figures 1 and 2 follow that the value added of CZK 1 employee compensation or as the case may be 1 CZK labour costs rise in the very year 2009 when the Czech economy was most affected by the global crisis. From more detailed analysis followed that the apparent contradiction is due to the fact that the power consumption of this year fell faster than performance. It should be borne in mind that in the value added are partly reflected the costs (output consumption), i.e. output affects not only the exercise price of food products, but also the cost of inputs. In 2010, on the contrary performances grew more slowly than the power consumption and thus it comes about the decline in labour productivity calculated from value added. Exclusion of large enterprises (EU classification) didnâ significantly affect the results of labour productivity surveyed of the company data. The obvious difference can be observed in the last year of monitoring (2012), where both the level and dynamics of labour productivity is higher in small and medium-sized enterprises.

The growth rates observed indicators (figure 2) show a similar development indicators monitored in the industry and company data, even though we can observe more intensity fluctuations from the sectoral data. If we focus on the results of the food businesses, it is particularly evident in 2012, while labour productivity in small and medium-sized businesses is growing, for all the firms in that year decreases (influence on drop this indicator for large enterprises, which may be affected by wage increases for example).

\section{Fig. 2: Growth rates of labour productivity}

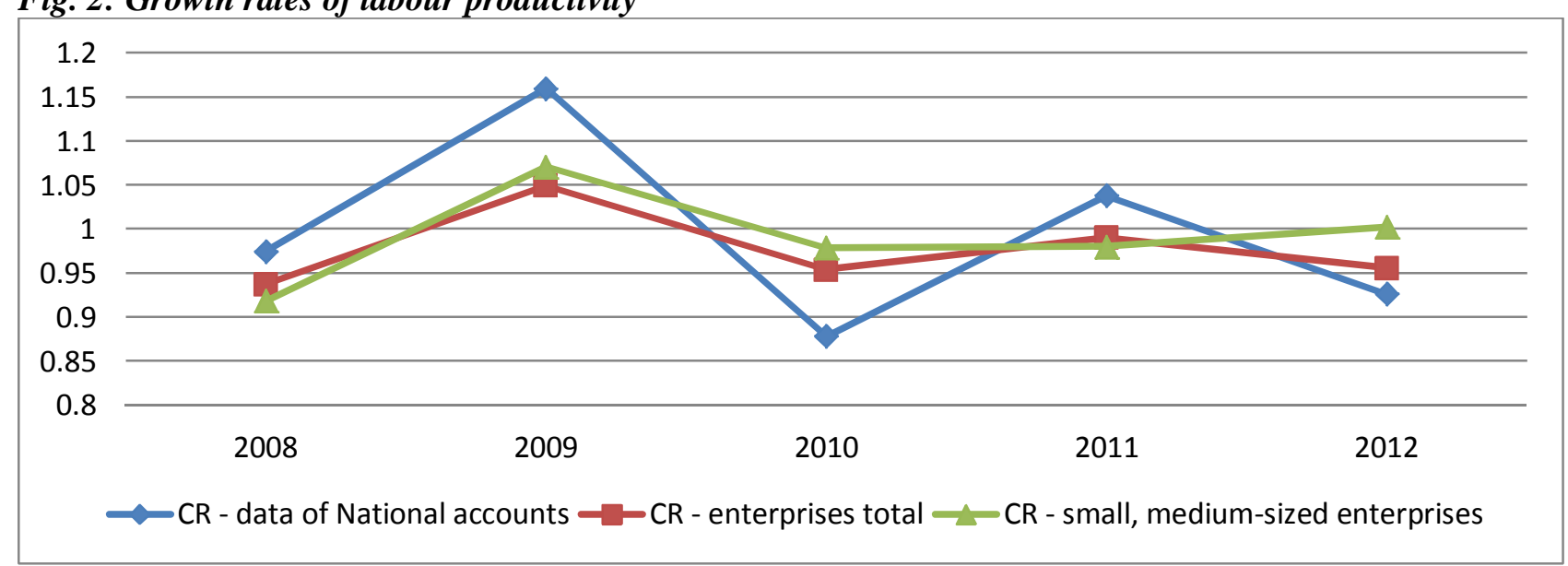

Source: Own calculations based on the data of National accounts, database ALBERTINA 
Small and medium enterprises were divided according to the NUTS2 classification into the partial administrative units in order to identify regional differences in progress of labour productivity.

In figure 3 is outlined the development of labour productivity for each region in the years $2007-2012$. It is clear that throughout the observation period, food businesses in StŚdní Morava and St\$́dní Lechy significantly exceed the average level of labour productivity.

Fig. 3: Labour productivity according to regions

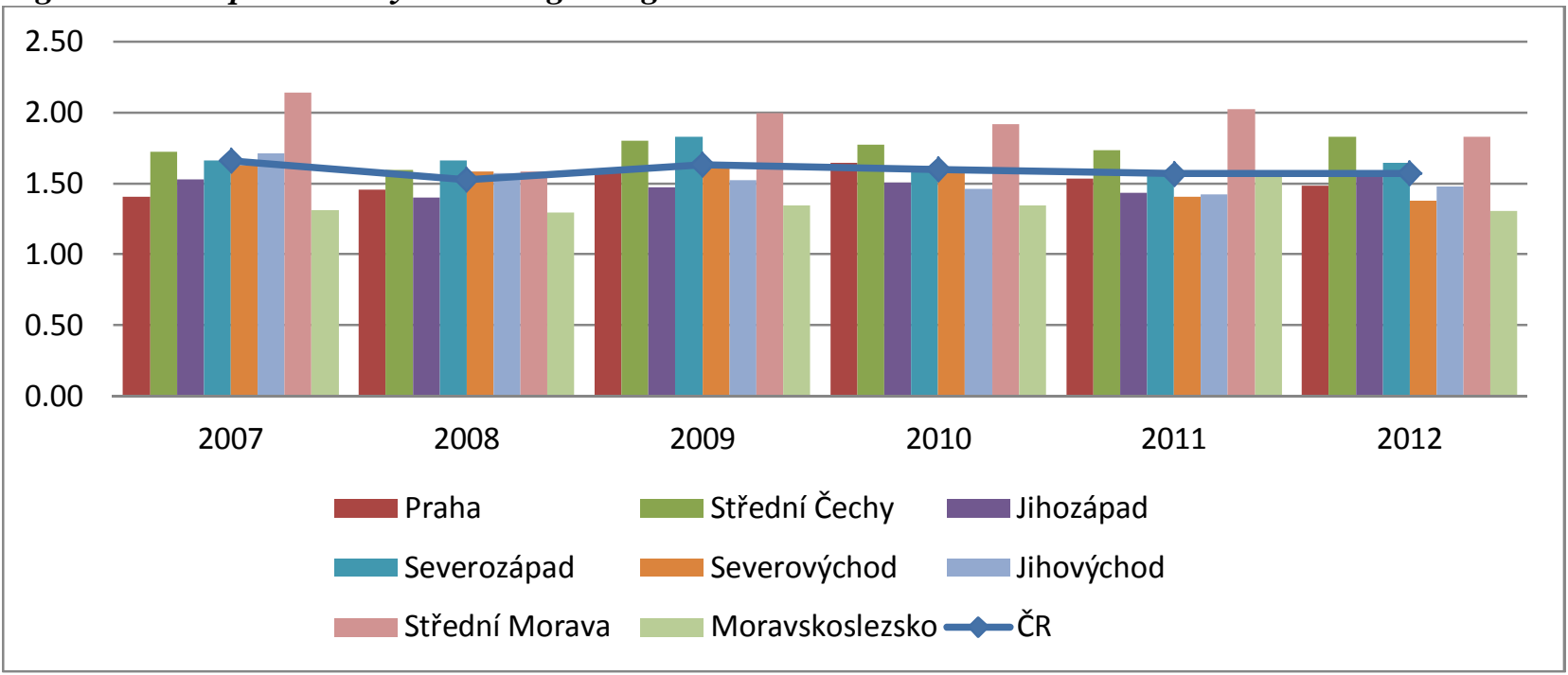

Source: Own calculations based on the database ALBERTINA

On the contrary, for the entire 6 years small and medium-sized businesses in Jihozápad and in Moravskoslezko are moving significantly below the average. The development of this indicator is also largely due to disparity in wages. It follows that Praha (Prague) is below average.

Fig. 4: Share of book value added in outputs (average for the period 2007-2012)

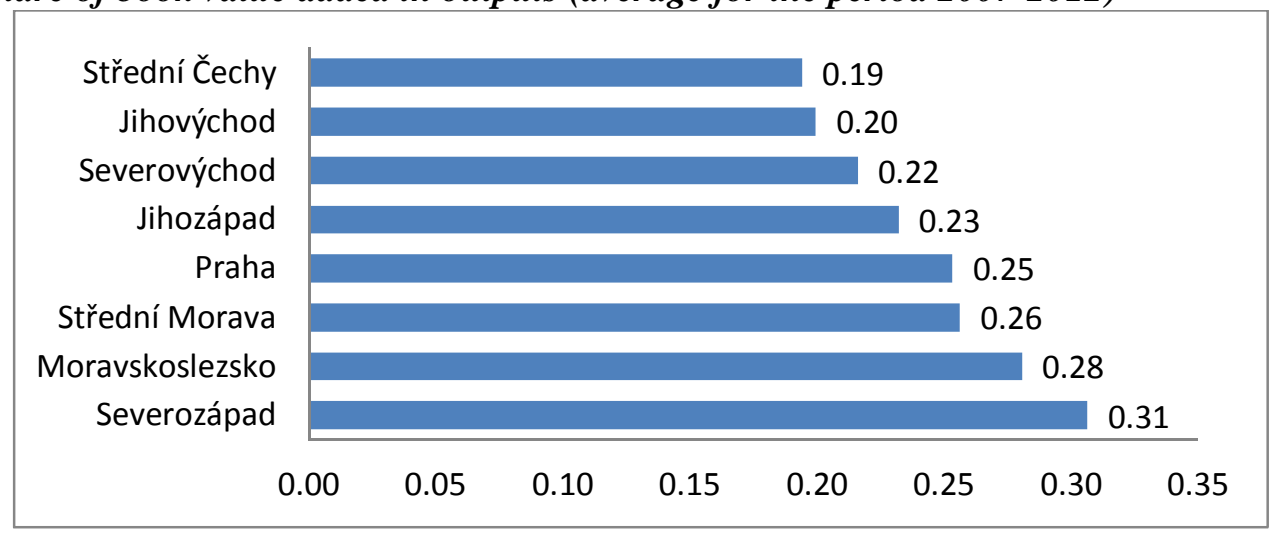

Source: Own calculations based on the database ALBERTINA

Figure 4 illustrates how much CZK of book value added is produced by one CZK of outputs. This ratio can also be seen as an indicator of the level of advancement of business activities. It is desirable that the $1 \mathrm{CZK}$ outputs fall on the highest value added. From this perspective, we can state a significant disparity in the regions. While enterprises in StŚední Lechy have above-average labour productivity, the share of book value added in outputs is the lowest (this share is about $88 \%$ of the national average $r$ for the Czech Republic (LR) ). Enterprises located in StŚední Morava, where labour productivity is the highest, have the third best ratio of book value added in outputs.

Another question is whether companies with above-average labour productivity in the regions also have above-average financial performance measured by indicators of profitability. 
Tab. 1: The average rate of growth of selected financial ratios for the period 2007-2012

\begin{tabular}{|l|c|c|c|c|}
\hline & Labour productivity & $\begin{array}{c}\text { Capital labour ratio } \\
\mathrm{I}_{\mathrm{CLR}}\end{array}$ & Capital productivity & Relations \\
\hline$\underline{\mathrm{L} R}$ & 0.989 & 0.995 & 0.994 & $<1$ \\
\hline Praha & 1.011 & 1.073 & 0.942 & $<1>$ \\
\hline StŚdní L̦echy & 1.012 & 0.974 & 1.039 & $1<$ \\
\hline Jihozápad & 1.004 & 0.985 & 1.019 & $1<$ \\
\hline Severozápad & 0.998 & 1.033 & 0.967 & $<$ \\
\hline Severovýchod & 0.968 & 0.968 & 0.999 & $<1$ \\
\hline Jihovýchod & 0.971 & 0.995 & 0.977 & $<1$ \\
\hline StŚ́dní Morava & 0.969 & 0.976 & 0.993 & $<1$ \\
\hline Moravskoslezsko & 0.999 & 1.064 & 0.939 & $<1$ \\
\hline
\end{tabular}

Based on the relationships between indicators (Tab. 1), food enterprises in the surveyed regions can be divided:

1. Group of companies in StŚední Lechy and the Severozápad could be characterized as economically successful. On average, for these firms both factors of production are developing positively. This variant of development is associated with the relative savings in tangible fixed assets due to the higher productivity of capital and the relative savings in labour costs due to the higher labour productivity. At the same time, however, there is a 5-year average decline in technical equipment (e.g. there may be a sale of unused buildings or land). The dynamics of value added is higher than the dynamics of labourcosts and tangible fixed assets, while the volume of tangible fixed assets is growing more slowly than the volume of labourcosts.

2. Contrarily, group of companies in the Severovýchod, Jihovýchod and StŚední Morava, Moravskoslezsko and Severozápad could be characterized as a group with unfavourable development of both factors of production on average in 5 years. The growth rate of labour costs and tangible fixed assets is higher than the growth rate of value added, i.e. that the dynamics of value added grows more slowly than the dynamics of both factors of production. In addition, on average in enterprises in the Severovýchod, Jihovýchod and StŚední Morava, the volume of labourcosts grows than the volume of fixed assets (technical work equipment decreases too). In companies in Moravskoslezsko and Severozápad is the development of these indicators opposite, so technical work equipment grows.

3. The group includes only companies in Praha, where relationships between indicators indicate the opposed development of production factors. A positive factor is the development of labour productivity and a negative factor is the development of capital productivity. This is to some extent linked to the increasing technical equipment of work. So the volume of fixed assets as well as the volume of value added grows faster than the costs of employees. Of course, the growth rate of value added is lower than the growth rate of fixed assets.

\section{Conclusion}

Introduced paper deals with regional difference in effectiveness of production factor labour at small and medium-sized enterprises in food industry.Authors found that the development productivity of labour at small and medium-sized enterprises in food industry is not developing in context development economy business cycle. Different development can be observed at these enterprises in comparison with average of Czech Republic, when small and medium sized enterprises achieve lower variability. From the regional standpoint (NUTS 2) authors found that the all along observation (2007 ï 2012) food industry enterprises in StŚdní Morava and StŚdní Lechy markedly exceed average values of labour productivity. On the contrary small and medium sized enterprises in Jihozápad region and in Moravskoslezko are below the average. On the basis of relationship among indicators productivity of labour, capital and capital-labour ratio were the food industry enterprises in monitored regions divided into on 3 groups. First group (includes enterprises in StŚdní L̦ echy and in Jihozápad) 
would be characterized as economically successful with positive development of productivity of labour and capital. Second group including enterprises in the Severovýchod, Jihovýchod and StŚední Morava, Moravskoslezsko and Severozápad regions would be conversely characterized as a group with unfavourable development of productivity of labour and capital. Third group, that include only enterprises in Prague, is defined with contradictory development. Productivity of labour develops positively and productivity of capital negatively. This apparition is due to raising technical equipment of labour. A similar finding for Prague was found by Zdenek a StŚlel ek (2012). Globally it is possible to say that the productivity of labour and its dynamic in particular regions has different size also development, that's largely affected by disparity in the field of wages in particular regions. Regions with highest wages have - not always most effective exploitation of production factor labour for example in Prague.

\section{References}

[1] ANTONelli, C., PATRUCCO, P. P., QUATRARO, F., (2011). Productivity Growth and Pecuniary Knowledge Externalities: An Empirical Analysis of Agglomeration Economies in European Regions. Economic Geography, vol. 87, iss. 1, pp. 23-50. tSSN 0013-0095. DOI 10.1111/j.1944-8287.2010.01104.x.

[2] BELORGEY, N., LECAT, R., MAURY, T. P., (2006). Determinants of productivity per employee: An empirical estimation using panel data. Economics Letters, vol. 91, iss. 2, pp. 153-157. tSSN 0165-1765. DOI 10.1016/j.econlet.2005.09.003.

[3] BERNANKE, B. S., PARKINSON, M. L., (1991). Procyclical labor productivity and competing theories of the business-cycle - some evidence from interwar united-states manufacturing-industries. Journal of Political Economy, vol. 99, iss. 3, pp. 439-459. tSSN 0022-3808. DOI 10.1086/261761.

[4] BROERSMA, L., OOSTERHAVEN, J., (2009). Regional labor productivity in the Netherlands: evidence of agglomeration and congestion effects. Journal of Regional Science, vol. 49, iss. 3, pp. 483-511. tSSN 0022-4146.DOI 10.1111/j.1467-9787.2008.00601.x.

[5] ENFLO, K. S., (2010). Productivity and employment-Is there a trade-off? Comparing Western European regions and American states 1950-2000. Annals of Regional Science, vol. 45, iss. 2, pp. 401-421. tSSN 0570-1864. DOI 10.1007/s00168-009-0315-6

[6] FIASCHI, D., LAVEZZI, A. M., (2007). Productivity polarization and sectoral dynamics in European regions. Journal of Macroeconomics, vol. 29, iss. 3, pp. 612-637. tSSN 0164-0704. DOI 10.1016/j.jmacro.2007.03.003.

[7] GUEST, R., (2011). Population ageing, capital intensity and labour productivity. Pacific Economic Review, vol. 16, iss. 3, pp. 371-388. tSSN 1361-374X. DOI 10.1111/j.1468-0106.2011.00553.x.

[8] LOPEZ-BAZO, E., VAYA, E., MORA, A. J., et al., (1999). Regional economic dynamics and convergence in the European Union. Annals of Regional Science, vol. 33, iss. 3, pp. 343-370. tSSN 0570-1864. DOI $10.1007 / \mathrm{s} 001680050109$.

[9] PIACENTINO, D., VASSALLO, E., (2011). Exploring the sources of labour productivity growth and convergence in the Italian regions: some evidence from a production frontier approach. Annals of Regional Science, vol. 46, iss. 2, pp. 469-486. tSSN 0570-1864. DOI 10.1007/s00168-009-0345-0 .

[10] PRESCOTT, E. C. LAWRENCE, R., (1998). Klein Lecture 1997: Needed: A Theory of Total Factor Productivity. International Economic Review, vol. 39, iss. 3, pp. 525-551. tSSN 00206598. DOI $10.2307 / 2527389$.

[11]RAMIK, J., NEVIMA, J., HANCLOVA, J., (2010). Multicriteria approaches to regional competitiveness and disparities. In International Conference on Regional Disparities in Central and Eastern Europe. Slovak Acad Sciences, Inst Economic Research. pp. 259-265. tSBN 978-80-7144-180-9.

[12] STř ELEL̦E, F., LOSOSOVÁ, J., (2003). An evaluation of the types of technical development in agriculture in the years 1995-2000. Agricultural Economics, vol.49, pp.151 - 165. ISSN 0139-570X.

[13] TRAVAGLINI, G., (2012). Trade-off between labor productivity and capital accumulation in Italian energy sector. Journal of Policy Modeling, vol. 34, iss. 1, pp. 35-48. tSSN 0161-8938. DOI 10.1016/j.jpolmod.2011.07.013.

[14]ZDENEK, R., STRELECEK, F., (2012). Evaluation Of Development Of Employment, Average Wage And Labour Productivity Using Shift-Share Analysis. E \& M Ekonomie a Management, vol. 15, iss. 3, pp. 4-15. tSSN 1212-3609.

This paper was supported by the Grant Agency of the University of South Bohemia GAJU 79/2013/S. 